\title{
RHEUMATOID FACTORS IN A RURAL POPULATION
}

\author{
BY \\ H. A. VAlkenburG, J. BALl, T. A. BURCH, P. H. BENNETT, \\ AND J. S. LAWRENCE \\ From the Institute for Rheumatism Research, University Hospital, Leiden, Netherlands, the National Institutes \\ of Arthritis and Metabolic Disease, Bethesda, U.S.A., the Rheumatism Research Centre, \\ University of Manchester, and the A.R.C. Field Unit, England
}

Epidemiological studies on the rheumatoid serum factors have indicated that anti-rabbit and antihuman globulin factors are evenly distributed between the sexes and in general show a direct relationship to age (Ball and Lawrence, 1961, Kissick, 1961). Some 20 to 30 per cent. of individuals with positive tests have shown evidence of rheumatoid arthritis but individuals with both antirabbit and anti-human factors are more likely to have clinical disease (Aho, Julkunen, Laine, Ripatti, and Wager, 1961; Mikkelsen, Dodge, Duff, Epstein, and Napier, 1961). The prevalence of positive tests has varied with age from 1 to 9 per cent. with the sheep cell agglutination test (SCAT) and from 0.5 to 4 per cent. with the latex-fixation test (LFT). The bentonite flocculation test (BFT) has revealed an increase from 2 to 13 per cent. of positive results with increasing age in American Indians. The SCAT has on the whole been found more often positive in urban populations, but the latex test has not been compared in this way. It has, however, shown considerable variation in different rural localities (Valkenburg, 1963). In this paper we present a comparison of sheep cell agglutination, latex, and bentonite flocculation tests in a rural population.

\section{Method}

The Wensleydale population sample, on which this study is based, included half the population of the market town of Hawes and half of the villages in the area. The method of sampling and technique of the survey has been described elsewhere (Bremner, 1961). The clinical and radiological assessments were made according to the Manchester gradings. The serum tests were performed according to the methods described in "The Epidemiology of Chronic Rheumatism" (Kellgren, 1963). Since this publication, the borderline titre of the LFT has been set at 640 because of the instability of the latex preparation. For the SCAT, a titre of 32 or more is regarded as positive.

\section{Results}

\section{Age and Sex Distribution}

Of the 509 males and 553 females in the sample 430 and 459 respectively had a latex fixation tes (LFT) of their serum (Table I). Of the males, 32 (7 per cent.) had a titre of 640 or more and were considered positive. Of the females, only eighteen (4 per cent.) fell within this range. There were thus significantly more positive tests in males than in females ( $\chi^{2}$ with Yates' correction 4.54; $\mathrm{P}<0.03$ ). There were, however, fewer low positive and more high positive titres in the females, so that when the

TABLE I

LATEX TITRES IN WENSLEYDALE (RANDOM SAMPLE), BY SEX AND AGE

\begin{tabular}{|c|c|c|c|c|c|c|c|c|c|c|c|c|c|c|}
\hline \multirow{2}{*}{ Sex } & \multirow{2}{*}{$\begin{array}{c}\text { Age } \\
\text { (yrs) }\end{array}$} & \multirow{2}{*}{$\begin{array}{c}\text { Total } \\
\text { in } \\
\text { Sample }\end{array}$} & \multicolumn{11}{|c|}{ Latex Titres } & \multirow{2}{*}{$\begin{array}{c}\text { Both } \\
\text { Sexes } \\
640+ \\
\text { (per cent.) }\end{array}$} \\
\hline & & & $\begin{array}{c}\text { Total } \\
\text { Tested }\end{array}$ & Neg. & 80 & 160 & 320 & 640 & 1,280 & 2,560 & 5,120 & $10,240+$ & $\begin{array}{c}640+ \\
\text { (per cent.) }\end{array}$ & \\
\hline \multirow[t]{2}{*}{ Male } & $\left.\begin{array}{r}15-24 \\
-34 \\
-44 \\
-54 \\
-64 \\
-74 \\
75+\end{array}\right\}$ & $\begin{array}{r}90 \\
72 \\
95 \\
108 \\
63 \\
81\end{array}$ & $\begin{array}{l}82 \\
60 \\
83 \\
86 \\
53 \\
41 \\
25\end{array}$ & $\begin{array}{l}73 \\
56 \\
73 \\
72 \\
45 \\
38 \\
21\end{array}$ & $\begin{array}{l}2 \\
2 \\
0 \\
0 \\
4 \\
0 \\
0\end{array}$ & $\begin{array}{l}3 \\
0 \\
0 \\
2 \\
0 \\
0 \\
1\end{array}$ & $\begin{array}{l}1 \\
1 \\
4\end{array}$ & $\begin{array}{l}2 \\
1 \\
4 \\
4 \\
3 \\
1 \\
1\end{array}$ & $\begin{array}{l}1 \\
4 \\
2 \\
1\end{array}$ & $\begin{array}{l}1 \\
1\end{array}$ & $\begin{array}{l}1 \\
1 \\
1\end{array}$ & $\begin{array}{l}1 \\
1\end{array}$ & $\begin{array}{r}4 \\
3 \\
11 \\
9 \\
8 \\
7 \\
12\end{array}$ & $\left.\begin{array}{l}2 \\
4 \\
8 \\
6 \\
7 \\
5 \\
9\end{array}\right\} 6$ \\
\hline & Total & 509 & 430 & 378 & 8 & 6 & 6 & 16 & 8 & 3 & 3 & 2 & 7 & \\
\hline \multirow[t]{2}{*}{ Female } & $\left.\begin{array}{r}15-24 \\
-34 \\
-44 \\
-54 \\
-64 \\
-74 \\
75+\end{array}\right\}$ & $\begin{array}{r}79 \\
79 \\
101 \\
86 \\
76 \\
132\end{array}$ & $\begin{array}{l}66 \\
66 \\
90 \\
73 \\
57 \\
75 \\
32\end{array}$ & $\begin{array}{l}66 \\
61 \\
83 \\
68 \\
48 \\
69 \\
28\end{array}$ & $\begin{array}{l}0 \\
0 \\
1 \\
2 \\
1 \\
2 \\
1\end{array}$ & $\begin{array}{l}0 \\
1 \\
0 \\
0 \\
3 \\
0 \\
0\end{array}$ & $\begin{array}{l}1 \\
2 \\
1 \\
1 \\
1 \\
1\end{array}$ & $\begin{array}{l}1 \\
1\end{array}$ & $\begin{array}{l}1 \\
1\end{array}$ & $\begin{array}{l}1 \\
1 \\
2\end{array}$ & $\begin{array}{l}1 \\
1 \\
1 \\
1 \\
1\end{array}$ & $\begin{array}{l}1 \\
2 \\
2\end{array}$ & $\begin{array}{l}0 \\
5 \\
4 \\
2 \\
7 \\
4 \\
6\end{array}$ & \\
\hline & Total & 553 & 459 & 423 & 7 & 4 & 7 & 2 & 2 & $4 *$ & 5 & 5 & 4 & \\
\hline
\end{tabular}


titre distribution was considered the sex difference was less striking (Fig. 1). The proportion of positive tests rose with age from 2 per cent. in those under 25 to 9 per cent. in those aged 75 and over but in an irregular fashion (Fig. 2). Only 4 per cent. of males and none of the females under the age of 25 had a positive test, but 12 per cent. of 25 males aged 75 and over had a positive test. The maximum positivity in the females was seen in the 55 to 64 and the $75+$ age groups, and the highest titres $(10,240$ and over) were present from age 55 onwards. The increase with age, though it confirms the findings of other workers, is not in itself significant.

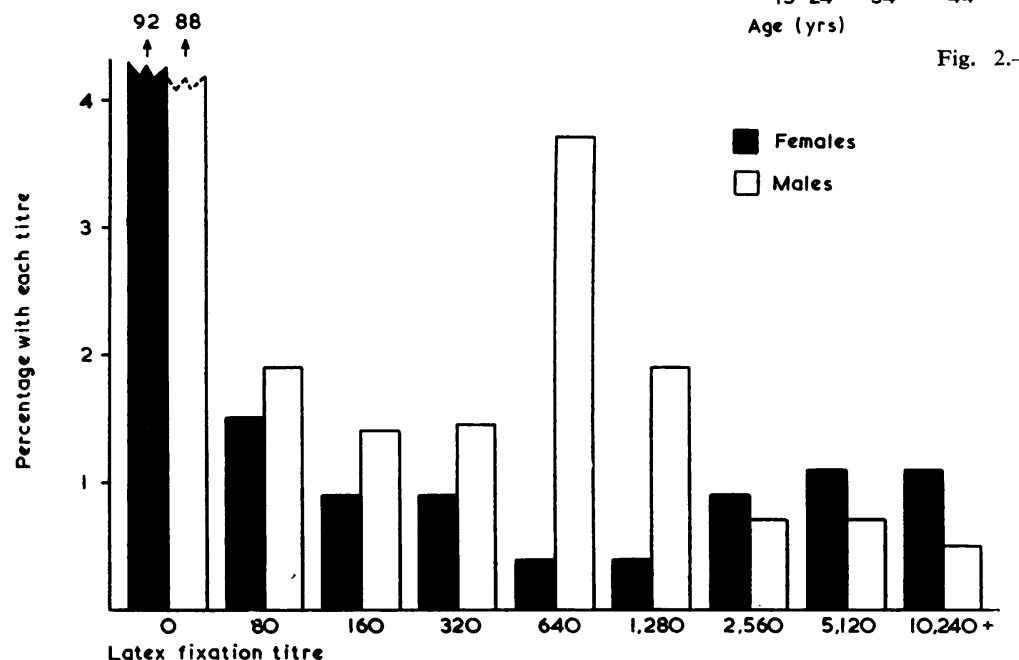

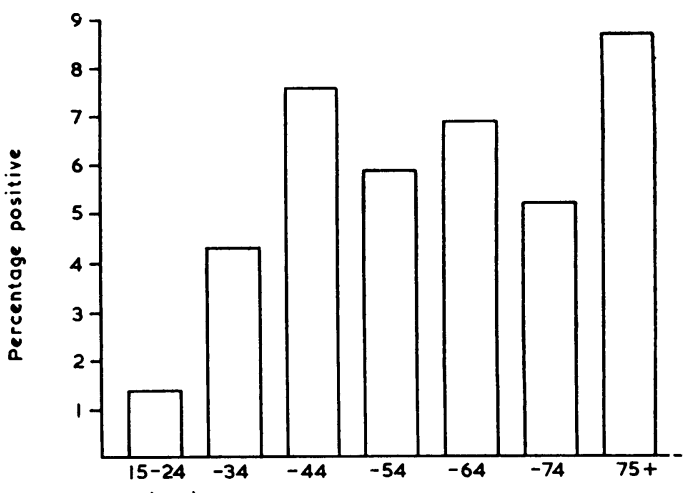

ig. 2.-Bentonite flocculation test in Wensleydale, by age.

Fig. 1.-Latex-fixation test 윻ำ Wenslevdale.

\section{Relationship of LFT to SCAT}

Altogether 889 samples were tested by both methods. When the LF and SCA titres in individual samples of serum were compared, a distinct relationship was observed (Table II). The four individuals with a sheep cell titre of 512 had an LF titre of
10,240 or more, and indeed all of the six with $\overrightarrow{\mathrm{B}}$ sheep cell titre of 128 or more had a positive LFB $(640+)$. Below this titre range the relationship was. less striking, half of those with a sheep cell titre of 3 . showing no agglutination by the LFT. Of the seven with an LF titre of 10,240 or more, two showed nबे

TABLE II

RELATIONSHIP OF LFT AND SCAT IN WENSLEYDALE SAMPLE TESTED BY BOTH METHODS

\begin{tabular}{|c|c|c|c|c|c|c|c|c|c|c|c|}
\hline \multirow{4}{*}{$\begin{array}{l}\text { Sheep Cell } \\
\text { Agglutination }\end{array}$} & Total & 801 & 15 & 10 & 13 & 18 & 10 & 7 & 8 & 7 & 889 \\
\hline & $\begin{array}{r}1024 \\
512 \\
256 \\
128 \\
64 \\
32\end{array}$ & $\begin{array}{l}1 \\
5\end{array}$ & & & & $\begin{array}{l}1 \\
1\end{array}$ & & $\begin{array}{l}1 \\
1\end{array}$ & $\begin{array}{l}1 \\
1 \\
4\end{array}$ & 4 & $\begin{array}{r}0 \\
4 \\
1 \\
1 \\
4 \\
10\end{array}$ \\
\hline & $\begin{array}{r}16 \\
8 \\
4 \\
<4\end{array}$ & $\begin{array}{r}5 \\
46 \\
57 \\
687\end{array}$ & $\begin{array}{r}1 \\
2 \\
12\end{array}$ & $\begin{array}{l}1 \\
1 \\
8\end{array}$ & $\begin{array}{r}1 \\
1 \\
11\end{array}$ & $\begin{array}{r}1 \\
1 \\
1 \\
13\end{array}$ & $\begin{array}{l}1 \\
2 \\
3 \\
4\end{array}$ & $\begin{array}{l}1 \\
1 \\
2 \\
1\end{array}$ & 2 & $\begin{array}{l}1 \\
2\end{array}$ & $\begin{array}{r}8 \\
54 \\
67 \\
740\end{array}$ \\
\hline & Titres & Neg. & 80 & 160 & 320 & 640 & 1,280 & 2,560 & 5,120 & $10,240+$ & Total \\
\hline \multicolumn{12}{|c|}{ Latex Fixation } \\
\hline \multicolumn{12}{|c|}{$\begin{array}{l}\text { Agreement on positive tests } 1.6 \text { per cent. } \\
\text { Disagreement } \\
4.7 \text { per cent. }\end{array}$} \\
\hline
\end{tabular}


agglutination by the SCAT, and at the marginal positive LF titre of 640 more than two-thirds had no agglutination with the SCAT.

The bentonite flocculation test (BFT) was carried out on half the Wensleydale sample (Ball, Bloch, Burch, Kellgren, Lawrence, and Tsigalidou, 1962). In four persons, the BFT was positive at a titre of 32 or more with a negative LFT (Table III). Two (W718, W510) had a titre of 32, one (W573) of 64, and one (W524) of 2,048. Only the last had a positive SCAT. Only one (W510) had any evidence of rheumatoid arthritis (RA); she had Grade 4 clinical and radiological evidence.

Both the BFT and LFT were positive in fifteen, of whom five had also a positive SCAT. Two of the five in whom all three tests were positive had RA as did two (W557 and 579) of the ten with a positive LFT and BFT and a negative SCAT. One of these (W579) had only radiological evidence. There were ten individuals in whom only the LFT was positive and none of these had any evidence of RA.

\section{Relationship of LFT to Rheumatoid Arthritis}

Of the 32 males in whom the LFT was positive at a titre of 640 or more, two (6 per cent.) had clinical evidence of RA (Grade 2-4), whereas of the eighteen sero-positive females, five ( 28 per cent.) had grade 2-4 RA (Table IV, p. 500). Thus 14 per cent. of persons with a positive LFT had clinical RA, but the proportion rose to 47 per cent. if only those with a titre above 2,560 were included.

Both the males and four of the five females with a titre of 10,240 or more had Grade 3-4 RA. The remaining female (who was aged 73 ) had only Grade 1 disease. She had had intermittent pain in the shoulders over the past 50 years and latterly had pain in the lower back and hips. There was slight swelling of the metacarpophalangeal joints in one hand. The $x$ rays showed evidence of RA only in the lumbar spine. None of the thirty remaining males with a positive LF test had clinical RA, though five were given a grading of 1 and therefore must be considered doubtful. Of the thirteen remaining sero-positive females, one had RA. On the other hand there were fourteen sero-negative males and 28 sero-negative females with Grade 2-4 clinical RA. Thus two rheumatoid males (12 per cent.) and five rheumatoid females (15 per cent.) had a positive test.

In Table $V$ and Fig. 3 (pp. 500, 501) a similar comparison is made between the grade of clinical RA and the SCAT in individuals having both SCAT and LFT positive. The distribution is rather different. The five Grade 2-4 rheumatoids who reacted with both systems (W76, 712, 57, 751, and 918) were spread over a wider titre range with the SCAT than with the LFT. The three sero-positive Grade 4 rheumatoids were positive by both tests, but of the five sero-positive Grade 3 rheumatoids only two (W712 and 76) were positive by both tests, two were positive only by the LFT, and one only by the SCAT. None of the Grade 2 rheumatoids was positive by either test.

With the LFT there was a gap between 640 and 2,560 in which no cases of RA were found. The lower limit of positive for the LFT could thuso equally be taken as 640 or 5,120 without affecting its ability to detect arthritis. With the SCAT, on the other hand, there was a fairly clear demarcation between 16 and 32 . Of the four males with a positive SCAT, one had clinical RA Grade 2-4. Of the sixteen sero-positive females, five (31 per cent.) were in Grade 2-4.

\section{Erosive Arthritis of the Hands or Feet}

Of the fifty persons with a positive LFT, $47 \mathrm{had}$ $x$ rays of the hands or feet, and eight of these (17 per cent.) had Grade 2-4 erosive arthritis (Table VI,

TABLE III

RELATIONSHIP OF LFT AND BFT IN WENSLEYDALE SAMPLE, TESTED BY BOTH METHODS

\begin{tabular}{|c|c|c|c|c|c|c|c|c|c|c|c|}
\hline \multirow{4}{*}{$\begin{array}{l}\text { Bentonite } \\
\text { Flocculation }\end{array}$} & Total & 332 & 3 & 2 & 7 & 9 & 5 & 3 & 6 & 2 & 369 \\
\hline & $\begin{array}{c}2,048+ \\
1,024 \\
512 \\
256 \\
128 \\
64 \\
32\end{array}$ & $\begin{array}{l}1 \\
1\end{array}$ & 1 & & & 4 & $\begin{array}{l}1 \\
1\end{array}$ & 1 & $\begin{array}{l}1 \\
1 \\
3 \\
1\end{array}$ & $\begin{array}{l}1 \\
1\end{array}$ & $\begin{array}{l}2 \\
2 \\
2 \\
3 \\
3 \\
7\end{array}$ \\
\hline & $\begin{array}{r}16 \\
8 \\
4 \\
<4\end{array}$ & $\begin{array}{r}8 \\
17 \\
23 \\
281\end{array}$ & 2 & 2 & $\begin{array}{l}2 \\
1 \\
1 \\
3\end{array}$ & $\begin{array}{l}1 \\
2 \\
2\end{array}$ & $\begin{array}{l}1 \\
1 \\
1\end{array}$ & 2 & & & $\begin{array}{r}12 \\
21 \\
24 \\
293\end{array}$ \\
\hline & Titres & Neg. & 80 & 160 & 320 & 640 & 1,280 & 2,560 & 5,120 & $10,240+$ & Total \\
\hline
\end{tabular}

Latex Fixation

Agreement on positive tests $4 \cdot 1$ per cent.
Disagreement 
TABLE IV RELATIONSHIP OF LF TITRE TO CLINICAL RA IN WENSLEYDALE
INDIVIDUALS IN WHOM BOTH SCAT AND LFT WAS PERFORMED

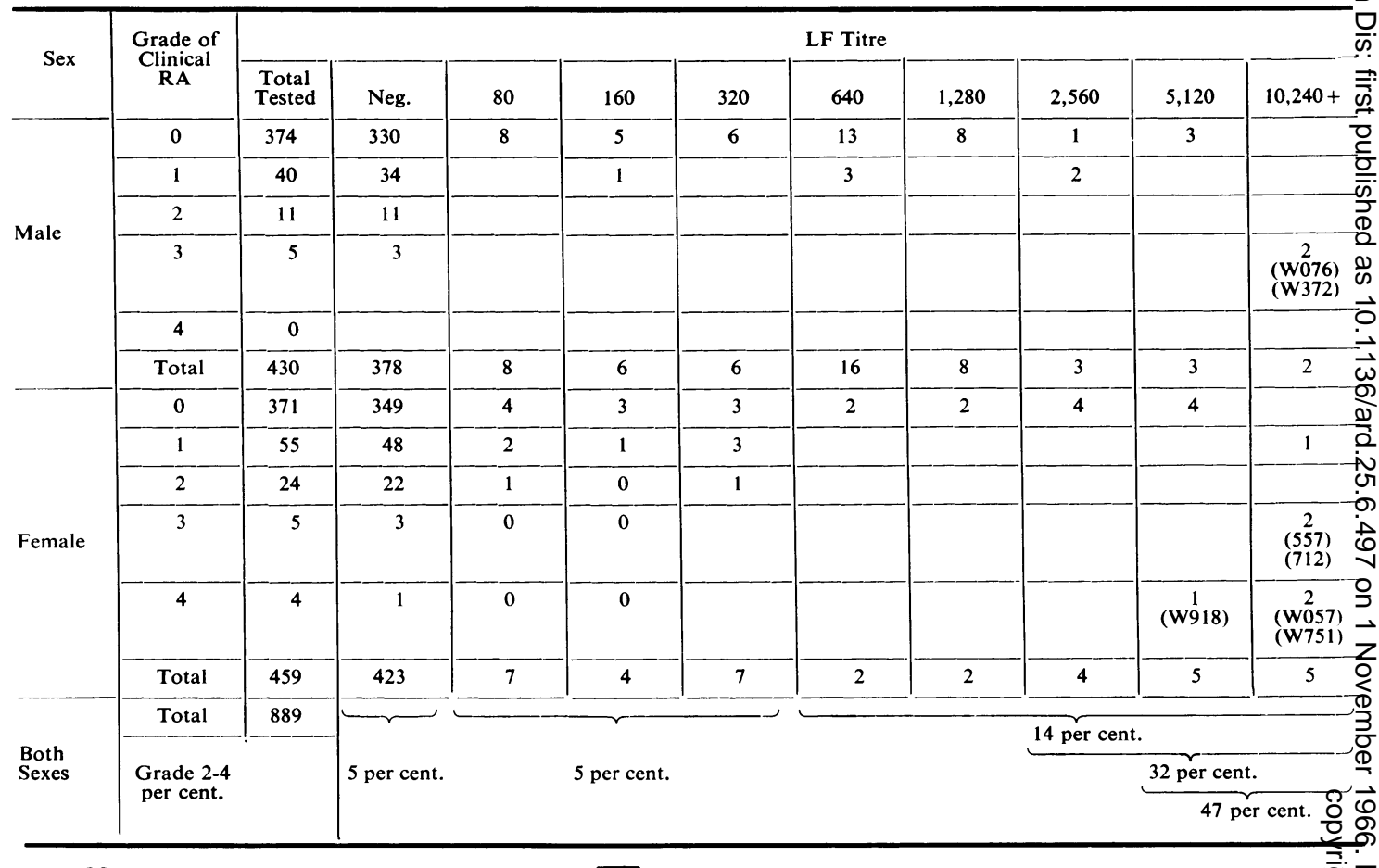

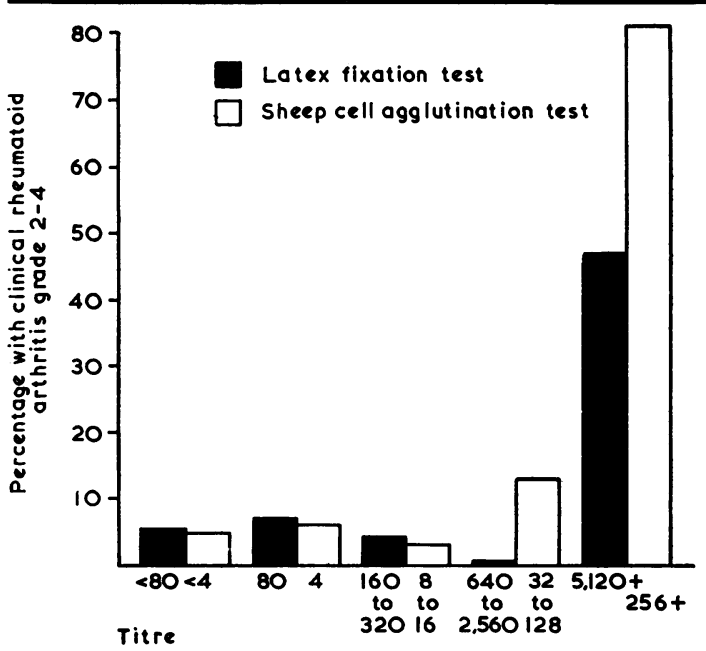

Fig. 3.-Relationship of latex-fixation test and sheep cell agglutination test to rheumatoid arthritis.

p. 502) - seven having also clinical evidence of arthritis. The eighth (W579) a male aged 89 had a negative SCAT, but had minimal erosive arthritis in the feet and cervical spine. A striking feature was the absence of definite erosive arthritis in those with titres of 80 to 2,560 and its presence in 53 per cent. of those with higher titres.
Erosive arthritis of the cervical spine showed same relationship to the LF titre as arthritis of the hands or feet, being present in 67 per cent. of those with titres of 5,120 or more (Table VII, p. 503).

\section{A.R.A. Criteria}

These were assessed using the SCAT as thi serological criterion. Probable or definite arthritis was present in 4 per cent. of those with a negative LFT, 9 per cent. with a titre of 80 to 320 , and 15 peè cent. of sero-positive individuals (Table VII p. 504).

However, six of the seven with a titre of 10,240 had probable or definite disease, the seventh being classified as possible. Those in the possible group with titres of 640 or more would have been classifieg as probable had the LFT result been used as criterion in the A.R.A. system, but this would have introduced a spurious correlation. The absence $\$ 6$ RA in those with titres of 640 to 2,560 confirms the finding in Table IV and indicates the close associag tion between the Manchester grading and the A.R.A criteria in sero-positive arthritis.

\section{Sensitivity and Specificity}

When the LFT and SCAT were directly comparea it was found that of twenty with a positive SCAฐ 
TABLE $\mathrm{V}$

RELATIONSHIP OF SCAT TO CLINICAL RA IN WENSLEYDALE INDIVIDUALS IN WHOM BOTH SCAT AND LFT WAS PERFORMED

\begin{tabular}{|c|c|c|c|c|c|c|c|c|c|c|c|c|}
\hline \multirow[b]{2}{*}{ Sex } & \multirow{2}{*}{$\begin{array}{c}\text { Grade of } \\
\text { Clinical } \\
\text { RA }\end{array}$} & \multicolumn{11}{|c|}{ Sheep Cell Agglutination Titre } \\
\hline & & $\begin{array}{l}\text { Total } \\
\text { Tested }\end{array}$ & $<4$ & 4 & 8 & 16 & 32 & 64 & 128 & 256 & 512 & 1,024 \\
\hline \multirow{6}{*}{ Male } & $\mathbf{0}$ & 374 & 322 & 27 & 19 & 3 & 2 & & & 1 & & \\
\hline & 1 & 40 & 31 & 5 & 3 & 1 & & & & & & \\
\hline & 2 & 11 & 11 & & & & & & & & & \\
\hline & 3 & 5 & 2 & & 2 & & & & & & $\begin{array}{c}1 \\
\text { (w076) }\end{array}$ & \\
\hline & 4 & 0 & & & & & & & & & & \\
\hline & Total & 430 & 366 & 32 & 24 & 4 & 2 & & & 1 & 1 & \\
\hline \multirow{6}{*}{ Female } & 0 & 371 & 300 & 29 & 28 & 4 & 7 & 2 & 1 & & & \\
\hline & 1 & 55 & 50 & 2 & 2 & & & 1 & & & & \\
\hline & 2 & 24 & 21 & 3 & & & & & & & & \\
\hline & 3 & 5 & 2 & 1 & & & $\begin{array}{c}1 \\
\left(W^{\prime} 69\right)\end{array}$ & & & & (W712) & \\
\hline & 4 & 4 & 1 & & & & & $\begin{array}{c}1 \\
\text { (W918) }\end{array}$ & & & $\begin{array}{c}2 \\
\text { (w057) } \\
\text { (w751) }\end{array}$ & \\
\hline & Total & 459 & 374 & 35 & 30 & 4 & 8 & 4 & 1 & & 3 & \\
\hline \multirow{2}{*}{$\begin{array}{l}\text { Both } \\
\text { Sexes }\end{array}$} & Total & 889 & 740 & 67 & 54 & 8 & 10 & 4 & 1 & 1 & 4 & \\
\hline & $\begin{array}{c}\text { Grade } \\
2-4 \\
\text { per cent. }\end{array}$ & & $\underbrace{}_{\begin{array}{c}5 \\
\text { per cent. }\end{array}}$ & & & & & & & & & \\
\hline
\end{tabular}

30 per cent. had both clinical and radiological RA compared with 14 per cent. of those with a positive LFT and 36 per cent. of those in whom both tests were positive (Table IX, p. 505). There were six in whom only the SCAT was positive, and one of these had clinical and radiological RA. There were 33 in whom only the LFT was positive, and two of these had clinical and radiological RA. Clinical and radiological evidence of $\mathrm{RA}$ was present in 1 per cent. of those with a negative SCAT, 1 per cent. of those with a negative LFT, and 1 per cent. of those in whom both tests were negative. None of those in whom both tests were positive had clinical RA without radiological evidence or radiological without clinical evidence. The numbers with only the SCAT or the LFT positive are too small for any conclusions to be drawn, but more of those in whom only the SCAT was positive tended to have RA.

The sensitivity and specificity of the two serum tests have been assessed using a formula devised by Cobb* (personal communication). The "specificity"

* For the assessment of symptoms and signs Ropes, Bennett, Cobb, Jacox, and Jessar (1959) recommended a different formula for specificity, defined as the number of persons without rheumatoid arthritis who do not meet the criterion divided by the total number of arthritis who do not meet the criterion divided by the total number of
persons who do not have rheumatoid arthritis. Using this formula, the specificity of the SCAT is $\frac{727}{740}=0.98$ and of thr LFT $\frac{704}{740}=0.95$ There is thus a less satisfactory separation bv this formula. in this formula is in reality a morbidity rate, but the term has been retained.

\begin{tabular}{l|c|c|c}
\hline \multirow{2}{*}{ Screen } & \multicolumn{2}{|c|}{ True } & Total \\
\cline { 2 - 3 } & Positive & Negative & \\
\hline Positive & A & B & A+B \\
Negative & C & D & C+D \\
\hline Total & A $+\mathbf{C}$ & B+D & A + B+C+D \\
\hline
\end{tabular}

$$
\text { Sensitivity }=\frac{\mathbf{A}}{\mathbf{A}+\mathbf{C}} \quad \text { Specificity }=\frac{\mathbf{A}}{\mathbf{A}+\mathbf{B}}
$$

In this instance the screen is the serum test and the "true" is clinical and/or radiological evidence of rheumatoid arthritis, as shown in Table IX.

Using this formula, the sensitivity of the SCAT as a detector of RA (clinical and/or radiological) is

$$
\frac{7}{125}=0.056 \text {, }
$$

and that of the LFT is

$$
\frac{11}{125}=0.088 \text {. }
$$


TABLE VI

RELATIONSHIP OF LFT TO RADIOLOGICAL EVIDENCE OF EROSIVE ARTHRITIS IN THE HANDS OR FEET IN WENSLEYDALE SAMPLE

\begin{tabular}{|c|c|c|c|c|c|c|c|c|c|c|c|c|c|}
\hline \multirow{2}{*}{ Sex } & \multicolumn{2}{|c|}{$\begin{array}{l}\text { Erosive Arthritis in } \\
\text { Hands and/or Feet }\end{array}$} & \multicolumn{11}{|c|}{ LF Titre } \\
\hline & Grade & $\begin{array}{l}\text { No. of } \\
\text { Cases }\end{array}$ & $\begin{array}{l}\text { Total } \\
\text { Tested }\end{array}$ & Neg. & 80 & 160 & 320 & 640 & 1,280 & 2,560 & 5,120 & $10,240+$ & N.S. \\
\hline \multirow{6}{*}{ Male } & 0 & 386 & 359 & 320 & 6 & 4 & 4 & 13 & 8 & 2 & 2 & & 27 \\
\hline & 1 & 40 & 38 & 34 & 1 & & 1 & 1 & & 1 & & & 2 \\
\hline & 2 & 13 & 11 & 10 & & & & & & & $\begin{array}{c}1 \\
(579)\end{array}$ & & 2 \\
\hline & 3 & 1 & 1 & & & & & & & & & $\begin{array}{c}1 \\
(372)\end{array}$ & \\
\hline & 4 & 2 & 2 & 1 & & & & & & & & $\begin{array}{c}1 \\
(076)\end{array}$ & \\
\hline & Total & 442 & 411 & 365 & 7 & 4 & 5 & 14 & 8 & 3 & 3 & 2 & 31 \\
\hline \multirow{6}{*}{ Female } & 0 & 440 & 400 & 371 & 7 & 4 & 6 & 2 & 2 & 3 & 4 & 1 & 40 \\
\hline & 1 & 38 & 34 & 33 & & & 1 & & & & & & 4 \\
\hline & 2 & 15 & 14 & 14 & & & & & & & & & 1 \\
\hline & 3 & 2 & 2 & & & & & & & & & $\begin{array}{c}2 \\
(557) \\
(751) \\
\end{array}$ & \\
\hline & 4 & 4 & 4 & 1 & & & & & & & $(918)$ & $\begin{array}{c}2 \\
(057) \\
(712)\end{array}$ & \\
\hline & Total & 499 & 454 & 419 & 7 & 4 & 7 & 2 & 2 & 3 & 5 & 5 & 45 \\
\hline \multirow{2}{*}{$\begin{array}{l}\text { Both } \\
\text { Sexes }\end{array}$} & & & 865 & \multirow{2}{*}{\multicolumn{4}{|c|}{$\underbrace{\begin{array}{r}3 \cdot 7 \\
\text { per cent. }\end{array}}$}} & 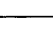 & $r$ & ـ & \multirow{2}{*}{\multicolumn{2}{|c|}{53 per cent. }} & \\
\hline & $\begin{array}{c}\text { Gra } \\
\text { per }\end{array}$ & 2-4 & & & & & & & per cent & & & & \\
\hline
\end{tabular}

The specificity of the SCAT is

$$
\frac{7}{20}=0 \cdot 35
$$

and that of the LFT is

$$
\frac{11}{47}=0 \cdot 23 \text {. }
$$

The LFT is therefore slightly more sensitive and the SCAT slightly more specific. If those with both tests positive are used in this assessment the sensitivity is reduced to $0 \cdot 040$, and the specificity is much the same as for the SCAT $(0 \cdot 36)$.

If only those with both clinical and radiological evidence of arthritis are used to assess sensitivity and specificity, the figures for sensitivity are higher and for specificity lower, since radiological evidence of erosions in the absence of clinical disease does not correlate with serology nor does clinical disease without radiological change, but the conclusions are the same, the sensitivity being 0.37 and 0.44 and the specificity $0 \cdot 30$ and $0 \cdot 14$ for the SCAT and LFT respectively.
Sensitivity and specificity have so far been assessech on the basis of a titre of 32 for the SCAT and $640 \mathrm{D}$ for the LFT, since these have been accepted as the lower limits of sero-positivity on the basis of studies on hospital patients. When the whole range of titre distributions was studied (Table X, p. 505) it be came clear that conclusions reached on specificiti were greatly influenced by the choice of cut-off point $\frac{}{2}$ If, for example, a titre of 5,120 were chosen as the lower limit for the LFT, this test became more specific than the SCAT at a titre of 32 and no les@ sensitive. It had about the same specificity as a SCAR of 64 but was more sensitive.

\section{Disk Degeneration}

When comparison was made between the grade of cervical disk degeneration and the LF titre, the mos: severe changes were found in those with the highes titres, but this was largely explicable by age distribu? tion. When correction was made for age there was no significant association.

Lumbar disk degeneration was similarly unrelate $\mathscr{C}^{\circ}$ to the LF titre. 
TABLE VII

EROSIVE ARTHRITIS OF THE CERVICAL SPINE IN RELATION TO LF TITRE

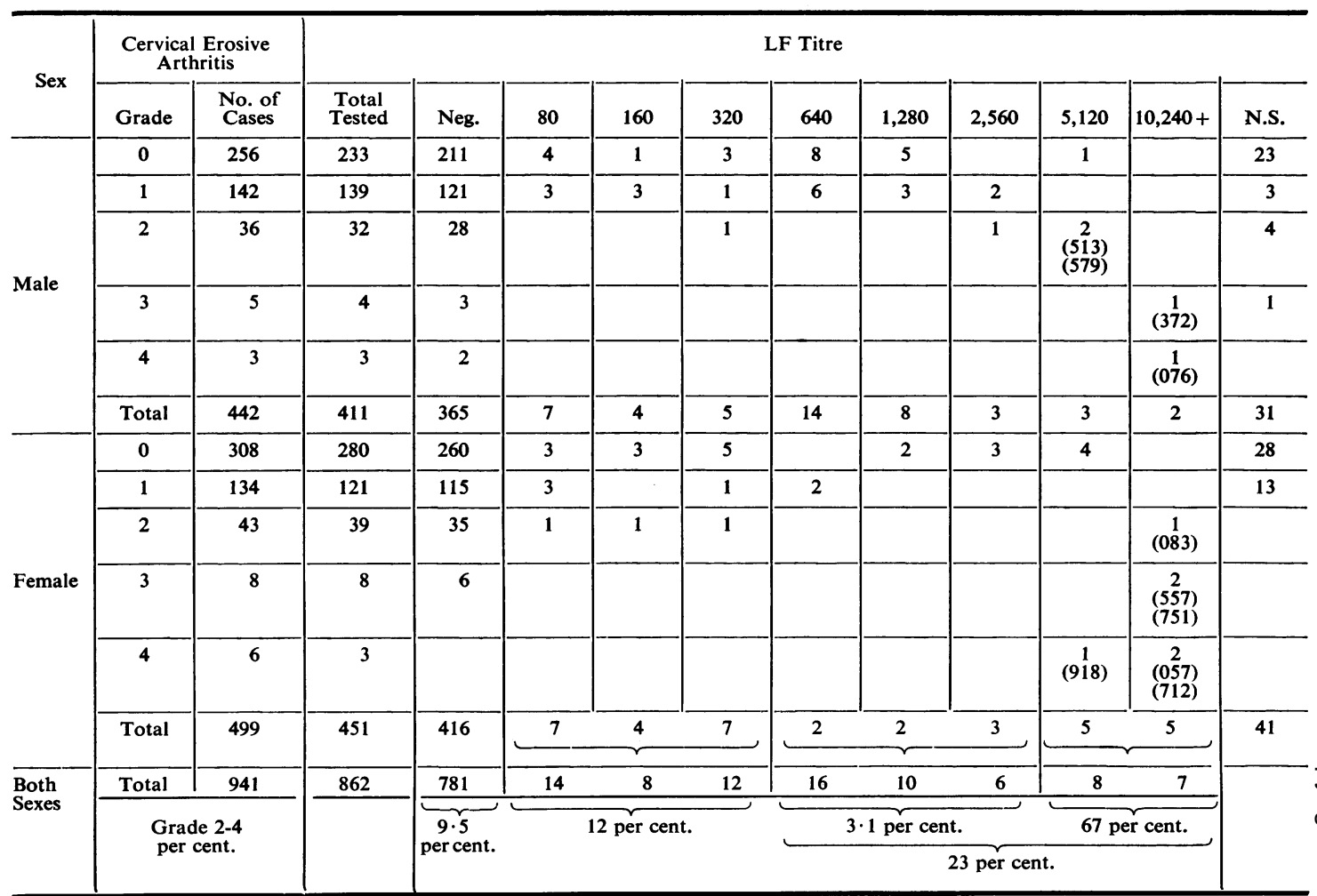

N.S. = not stated.

\section{Oste0-arthrosis}

This was present in five or more joints in 9 per cent. of males with a positive LFT (Table XI, p. 505). This is much the same proportion as was found in those with a negative or intermediate LF titre. On the other hand 22 per cent. of females with a positive LFT had osteo-arthrosis in five or more joints and 28 per cent. of those with intermediate titres, compared with only 12 per cent. of those with a negative test. The association was not significant but such as it was it appeared to be in the non-nodal type of generalized osteo-arthrosis.

Of the eighteen females with non-nodal osteoarthrosis in five or more joints, 11 per cent. had a positive LFT compared with 5 per cent. of the 42 females with nodal osteo-arthrosis. A similar trend is discernible in the males.

\section{Discussion}

The Wensleydale sample was unusual in that it showed an increase of the SCA titre with age only in females. None of the males aged 55 and over had a positive SCAT. The LFT on the other hand increased with age in both sexes. The reason for this discrepancy is not apparent. It was quite unrelated to rheumatoid arthritis which increased with age in males despite the absence of anti-rabbit globulin factor in the older males. Half of these older males with arthritis had disease of moderate severity and all were free of symptoms. The remainder were of minimal severity.

Burch (1963) has suggested that a positive SCAT due to infection would be less likely in a rural than in an urban population and that when it did occur it would be secondary to the arthritis and therefore more common in females. In fact 40 per cent. of the 21 persons with a positive SCAT in Wensleydale had clinical or radiological evidence of RA, whereas in Leigh, of the 73 individuals, only 22 per cent. had such evidence. The absence of a positive SCAT in the older males with RA, however, does not support this contention. The relatively isolated life of many 
TABLE VIII

A.R.A. CRITERIA* IN RELATION TO LF TITRE

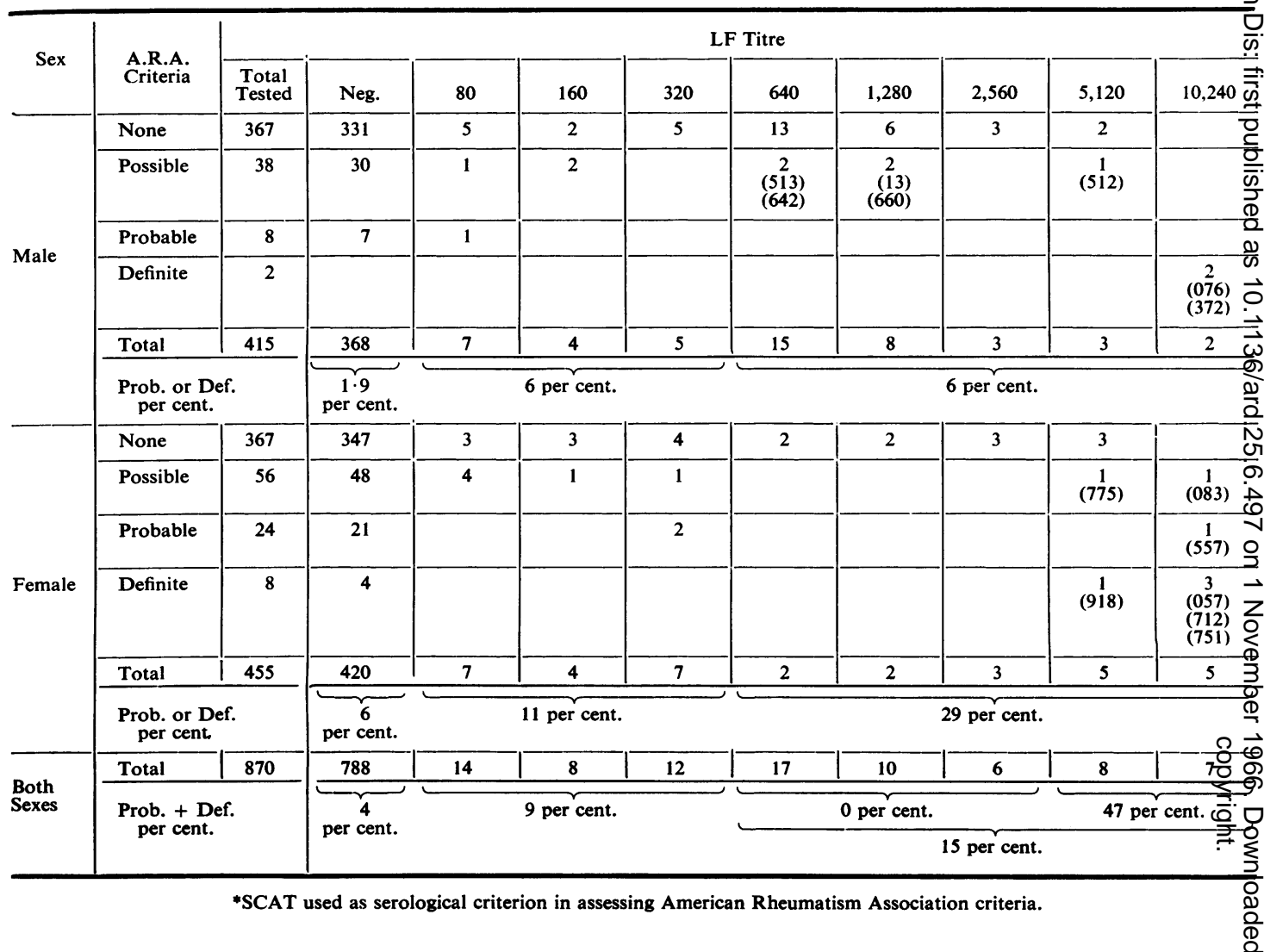

of the males in Wensleydale, particularly the older sheep farmers before the motor car became generally available, might understandably result in a low incidence of infection. Also a sero-positive rheumatoid farmer would tend to opt out of a farming population. A low prevalence of positive SCA titres in males has not, however, been a feature of all rural populations. In a rural population sample in Jamaica, there were more positive SCA titres in males, and Bunim, Burch, and O'Brien (1964) found identical prevalences in males and females in a rural population in Montana. In the population of Oberhörlen in West Germany, there were five times as many positive SCA titres in the males (Behrend and Lawrence, 1966).

Discrepancies between the latex and bentonite flocculation tests are surprising, since human FII globulin is used as substrate in both tests. The bentonite tests were repeated on four discrepant sera which had been negative to the BFT and positive to the LFT, but only one gave a positive BFT (at a titre of 32) the second time. In another the titri had risen to 16 , but the other two showed no evidence of agglutination. On the occasion of the second test the serum was 6 years old and was showing evidence of denaturation despite storage at $-15^{\circ} \mathrm{d}$ As judged from tests on other sera of the same age this seemed to have the effect of increasing the pros portion of positives. It is therefore more likely that the initial test was correct.

Glynn (1962) has shown that, if protein is adsorbeg on to latex and on to bentonite, the configuration is quite different. In the first there is a marked in crease of titratable sulphydril groups, and in the other a fall in sulphydril groups, showing that the molecules that have attached themselves to the lated have a different configuration from those bindind themselves to the bentonite particles. If rabbits are immunized with bovine $\gamma$ globulin adsorbed on these two particles, the antibody response is not identical. In the rabbits immunized with bentonite coated particles the antibody will agglutinate 
TABLE IX

SENSITIVITY AND SPECIFICITY OF SCAT AND LFT IN RELATION TO RA IN WENSLEYDALE PERSONS IN WHOM $X$ RAYS OF THE HANDS, FEET, AND NECK, AND BOTH SERUM TESTS WERE CARRIED OUT

\begin{tabular}{|c|c|c|c|c|c|c|c|c|c|}
\hline \multirow{3}{*}{ Total Tested } & \multirow{3}{*}{$\begin{array}{c}\begin{array}{c}\text { Total } \\
x \text { rayed }\end{array} \\
865\end{array}$} & \multicolumn{2}{|c|}{$\begin{array}{l}\text { Clinical } \\
\text { RA } \\
\text { only }\end{array}$} & \multicolumn{2}{|c|}{$\underset{\text { RA }}{\text { Radinical }+}+$} & \multicolumn{2}{|c|}{$\begin{array}{c}\text { Radiological Erosive } \\
\text { Arthritis Only } \\
\text { Grade 2-4 }\end{array}$} & \multicolumn{2}{|c|}{$\begin{array}{c}\text { Total } \\
\text { RA }\end{array}$} \\
\hline & & \multicolumn{2}{|c|}{33} & \multicolumn{2}{|c|}{16} & \multicolumn{2}{|c|}{76} & \multicolumn{2}{|c|}{125} \\
\hline & & No. & Percentage & No. & Percentage & No. & Percentage & No. & Percentage \\
\hline $\begin{array}{l}\text { SCAT + } \\
\text { LFT + } \\
\text { SCAT + LFT + } \\
\text { SCAT - } \\
\text { LFT - }\end{array}$ & $\begin{array}{r}20 \\
47 \\
14 \\
845 \\
818\end{array}$ & $\begin{array}{r}0 \\
0 \\
0 \\
0 \\
33 \\
33\end{array}$ & $\begin{array}{l}0 \\
0 \\
0 \\
4 \\
4\end{array}$ & $\begin{array}{r}6 \\
7 \\
5 \\
10 \\
9\end{array}$ & $\begin{array}{r}30 \\
14 \\
36 \\
1 \\
1\end{array}$ & $\begin{array}{r}1 \\
4 \\
0 \\
75 \\
72\end{array}$ & $\begin{array}{l}5 \\
9 \\
0 \\
9 \\
9\end{array}$ & $\begin{array}{r}7 \\
11 \\
5 \\
118 \\
114\end{array}$ & $\begin{array}{l}35 \\
23 \\
36 \\
14 \\
14\end{array}$ \\
\hline SCAT - LFT - & 812 & 33 & 4 & 8 & 1 & 71 & 9 & 112 & 14 \\
\hline $\begin{array}{l}\text { SCAT Only + } \\
\text { LFT Only + }\end{array}$ & $\begin{array}{r}6 \\
33\end{array}$ & $\begin{array}{l}0 \\
0\end{array}$ & $\begin{array}{l}0 \\
0\end{array}$ & $\begin{array}{l}1 \\
2\end{array}$ & $\begin{array}{r}17 \\
6\end{array}$ & $\begin{array}{l}1 \\
4\end{array}$ & $\begin{array}{l}17 \\
12\end{array}$ & $\begin{array}{l}2 \\
6\end{array}$ & $\begin{array}{l}33 \\
18\end{array}$ \\
\hline
\end{tabular}

TABLE $\mathbf{X}$

SPECIFICITY AND SENSITIVITY OF SCAT AND LFT FOR CLINICAL RA GRADE 2-4 IN WENSLEYDALE

\begin{tabular}{|c|c|c|c|c|c|c|c|c|}
\hline \multirow{2}{*}{ SCAT } & \multicolumn{8}{|c|}{ Titre } \\
\hline & $\geqslant 4$ & $\geqslant 8$ & $\geqslant 16$ & $\geqslant 32$ & $\geqslant 64$ & $\geqslant 128$ & $\geqslant 256$ & $\geqslant 512$ \\
\hline $\begin{array}{l}\text { Sensitivity } \\
\text { Specificity }\end{array}$ & $\begin{array}{l}0 \cdot 24 \\
0 \cdot 08\end{array}$ & $\begin{array}{l}0 \cdot 16 \\
0 \cdot 10\end{array}$ & $\begin{array}{l}0 \cdot 12 \\
0 \cdot 21\end{array}$ & $\begin{array}{l}0 \cdot 12 \\
0 \cdot 30\end{array}$ & $\begin{array}{l}0 \cdot 10 \\
0 \cdot 50\end{array}$ & $\begin{array}{l}0 \cdot 082 \\
0 \cdot 67\end{array}$ & $\begin{array}{l}0 \cdot 082 \\
0 \cdot 80\end{array}$ & $\begin{array}{l}0 \cdot 082 \\
1 \cdot 00\end{array}$ \\
\hline LFT & $\geqslant 80$ & $\geqslant 160$ & $\geqslant 320$ & $\geqslant 640$ & $\geqslant 1,280$ & $\geqslant 2,560$ & $\geqslant 5,120$ & $\geqslant 10,240$ \\
\hline $\begin{array}{l}\text { Sensitivity } \\
\text { Specificity }\end{array}$ & $\begin{array}{l}0 \cdot 18 \\
0 \cdot 10\end{array}$ & $\begin{array}{l}0 \cdot 16 \\
0 \cdot 11\end{array}$ & $\begin{array}{l}0 \cdot 16 \\
0 \cdot 13\end{array}$ & $\begin{array}{l}0 \cdot 14 \\
0 \cdot 14\end{array}$ & $\begin{array}{l}0 \cdot 14 \\
0 \cdot 22\end{array}$ & $\begin{array}{l}0 \cdot 14 \\
0 \cdot 32\end{array}$ & $\begin{array}{l}0 \cdot 14 \\
0 \cdot 47\end{array}$ & $\begin{array}{l}0 \cdot 12 \\
0 \cdot 86\end{array}$ \\
\hline
\end{tabular}

TABLE XI

RELATIONSHIP OF OSTEO-ARTHROSIS TO LFT IN WENSLEYDALE

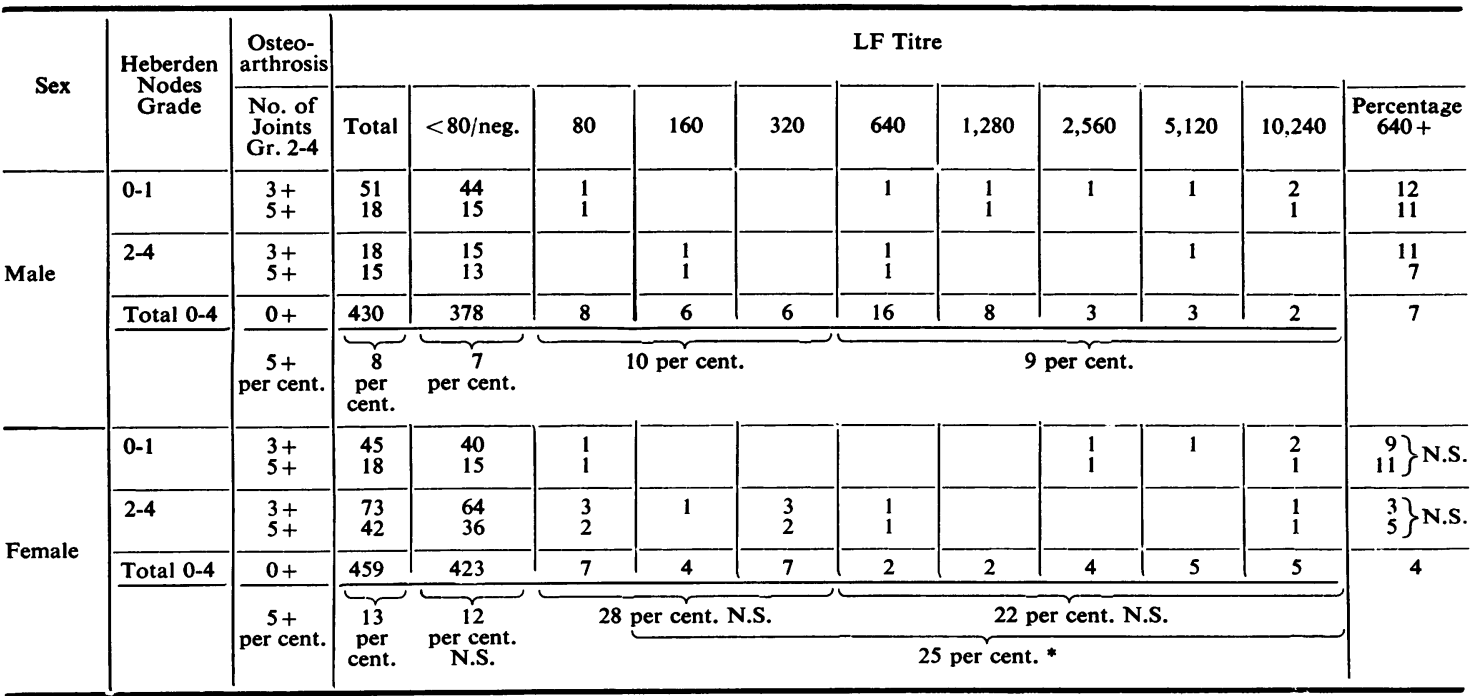

N.S. $=$ Not significant.

${ }^{*} \chi^{2}$ with Yates' correction $=3.8184 ; \mathrm{P}<0.06$

$x^{2}=1.752 ; P<0.09$ (Difference of proportions) 
bentonite-coated particles but will scarcely agglutinate latex. In the other it will agglutinate latex particles and scarcely agglutinate bentonite. Glynn attributes this to the fact that latex is a non-polar particle whereas bentonite is polar. This, he thinks, causes the unfolding of the proteins in a different way. This may possibly explain the discrepancies, though a similar degree of discrepancy has been noted by one of us in random sample sera tested by two different latex tests. Comparison of two tests using sheep and human red cells as carriers for rabbit amboceptor has also shown similar discrepancies (Valkenburg, 1965). The absence of RA in those in whom the LFT only was positive would suggest that this factor carries a better prognosis, but the numbers are too small for any definite conclusion. It should be observed that the latex test was carried out at a later date than the original BFT and the serum may have deteriorated to some extent.

Discrepancies between the LFT and the SCAT are well recognized in population samples (Ball, Bloch, Burch, Kellgren, Lawrence, and Tsigalidou, 1962; Ball, De Graaff, Valkenburg, and Boerma, 1962), but the tests are concordant more often than would be expected by chance. This could be due to a common aetiology affecting multiple factors or to the occurrence of a single rheumatoid factor which reacts with both systems. Such a factor has been found in patients with RA by Heimer and Schwartz (1961) and Williams and Kunkel (1963), and the greater prevalence of RA in those in whom both tests were positive in the Wensleydale population sample and also in the Heinola survey reported by Aho and others (1961) supports the theory that RA is associated with a single factor reacting with both systems.

This survey confirms the greater specificity of the SCAT at the titres used to denote sero-positivity in hospital practice, but reveals only a slightly greater sensitivity of the LFT in contrast to reports from hospital series. It suggests that a narrower definition of sero-positivity with the latex test might be more meaningful. By increasing the borderline of the LFT to 5,120 there is no loss of sensitivity, but a striking increase in specificity, which to a certain extent is also true for the SCAT. Generalizing this would mean that two occurrences take place at the same time. The higher the titre in any test system the greater the specificity but at the same time the concordance between the test systems increases. In other words the longer the contact with the "antigen" the more likely is it that the "antibody" will be produced, and the more likely is it that clinical and/or radiological disease will occur. At the same time the longer exposure to the antigen increases the heterogeneity of the antibody molecules, which is a familiar phenomenon in immunology. The increase in heterogeneity means more antibodies to differen antigenic sites and therefore a better correlation between different test-systems. The selection due to a longer exposure to antigen increases the chances of developing "immunological" disease and hence clinical rheumatoid arthritis, which in itself, being more severe, tends to select itself towards the clini $\frac{\bar{\xi}}{5}$ The result is not only a higher incidence of positive rheumatoid serology in clinic patients, but also $Q$ different distribution of titres tending towards higher titres as compared with those found if arthritics from population samples. Thus a feature of this, as of other population surveys, is the smatl proportion of arthritics in Wensleydale with positive tests compared with the proportion of 70 to 80 pes cent. usually reported in hospital patients. Nojis surprisingly it is those with minimal disease ib Wensleydale who had negative tests. None of those with only Grade 2 clinical disease had an LF titre of more than 320 or an SCA titre of more than Of those with Grade 3-4 disease, 50 per cent. had a positive LFT and 43 per cent. a positive SCAT SC $^{Z}$ Even this is less than in most series of hospitan patients. Of the four with Grade 4 disease, three were positive by either test. Partly, however, it maפ depend on the stage of the disease at which the test is performed. Arthritics are usually referred hospital during the active stage of the diseasse? Though the titre of rheumatoid factors does follow closely the degree of activity of the disease there is evidence that the titre tends to fall durin prolonged remissions.

The evidence of an association between the latex titre and generalized osteo-arthrosis of non-noda $\vec{E}$ type, though tentative, is of interest in view of the association of this condition with rheumatoid arthritis in family studies (Kellgren, Lawrence, and Bier, 1963). The SCAT was not found to be increased in these families.

The findings in this survey raise the question which test system should be used in population studies: Since neither the SCAT nor the FII globulin tests will detect all sero-positive rheumatoid arthritis we consider that both should be used.

\section{Summary}

A rural population sample in the North of Eng land, comprising 430 males and 459 females aged 150 and over, has been subjected to a routine test of thew serum by the latex fixation test for rheumatoide factor reacting with FII human $\gamma$ globulln and by theo sheep cell agglutination test for rheumatoid factor reacting with rabbit $\gamma$ globulin.

A positive titre of 640 or more by the LFT was? 
found in 7 per cent. of males and 4 per cent. of females, whereas with the SCAT 1 per cent. of males and 3 per cent. of females were positive. The proportion of positive latex fixation tests increased with age from 2 per cent. at age 15-24 to 9 per cent. at age 75 and over. The increase with age was nonlinear, and was present in both sexes. Fourteen of the sera were positive by both the SCAT and LFT, 36 were positive by the LFT only, and six were positive by the SCAT only. The number with both tests positive was greater than would be expected by chance.

A bentonite flocculation test was carried out only in the second half of the survey. Of the 369 sera tested by the BFT and LFT, fifteen were positive by both tests, four by the BFT only, and ten by the LFT only. The concordance between the BFT and LFT was thus 52 per cent. and that between the LFT and SCAT was 25 per cent. of positive tests.

Clinical or radiological evidence of rheumatoid arthritis was found in five of the fourteen in whom both SCAT and LFT were positive, in one of the six in whom the SCAT only was positive, but in only two of the 33 in whom the LFT only was positive.

Of the fifteen individuals with a latex fixation titre of 5,120 or more, ten had other evidence of rheumatoid arthritis. All had erosive arthritis of the cervical spine, eight had erosions of the hands or feet on $x$ ray, and seven had clinical arthritis.

This study confirms the greater specificity of the sheep cell agglutination test as used in hospital practice, but indicates that the latex test would be more meaningful if a narrower definition of seropositivity were used.

We wish to express our thanks to the people of Wensleydale who generously took part in this survey.

\section{REFERENCES}

Aho, K., Julkunen, H., Laine, V., Ripatti, N., and Wager, O. (1961). Acta rheum scand., 7, 201.

Ball, J., Bloch, K. J., Burch, T. A., Kellgren, J. H., Lawrence, J. S., and Tsigalidou, V. (1962). Arthr. and Rheum., 5, 61.

_-, De Graaff, R., Valkenburg, H. A., and Boerma, F. W. (1962). Ibid., 5, 55 .

- and Lawrence, J. S. (1961). Ann. rheum. Dis., 20, 235.

Behrend, T., and Lawrence, J. S. (1966). In "Symposium on Population Studies", Proc. int. Congr. Rheum., Mar del Plata, Argentina.

Bremner, J. M. (1961). Ann. rheum. Dis., 20, 149.

Bunim, J. J., Burch, T. A., and O'Brien, W. M. (1964). Bull. rheum. Dis., 15, 349.

Burch, P. R. J. (1963). Lancet, 1, 1253.

Glyn, L. E. (1962). In "Conference on Rheumatic Diseases, 1962, Ashridge College, Berkhamsted". Nuffield Foundation.
Heimer, R., and Schwartz, E. R. (1961). Arthr. and Rheum., 4, 153.

Kellgren, J. H. (ed.) (1963). "Epidemiology of Chronic Rheumatism", vol. 1, p. 328. Blackwell, Oxford.

- Lawrence, J. S., and Bier, F. (1963). Ann. rheum. Dis., 22, 237.

Kissick, W. L. (1961). Arthr. and Rheum., 4, 424.

Lawrence, J. S. (1963). Ibid., 6, 166.

Mikkelsen, W. M., Dodge, H. J., Duff, I. F., Epstein, F. H., and Napier, J. A. (1961). "Eighth Interim Scientific Session of the A.R.A.”, p. 24.

Ropes, M. W., Bennett, G. A., Cobb, S., Jacox, R., and Jessar, R. A. (1959). Ann. rheum. Dis., 18, 49.

Valkenburg, H. A. (1963). In Kellgren (1963), p. 74.

(1965). In "Comparability in International Epidemiology", ed. R. M. Acheson. Milbank Mem. Fund Quart., 43, No. 2, pt 2, p. 153.

Williams, R. C., and Kunkel, H. G. ('963). Arthr. and Rheum., 6, 665.

\section{Les facteurs rhumatoïdes dans une popuration rurale}

\section{RÉSUMÉ}

Un échantillon de population rurale du Nord de l'Angleterre, comprenant 430 hommes at 459 femmes, âgés de 15 ans ou plus, a été soumis a des examens sérologiques systématiques destinés à la recherche du facteur rhumatoïde par test de fixation au latex réagissant avec les globulines humaines du groupe F II et par la réaction de Waaler-Rose réagissant avec les $a$-globulines de lapin.

La réaction fut positive à un titre de $1 / 640$ ou supérieuz pour le test au latex chez 7 pour cent des hommes et chez 4 pour cent des femmes, tandis que la réaction dé Waaler-Rose fut positive chez un pour cent des hommes et 3 pour cent des femmes. La proportion des tests au latex positifs augmenta avec l'âge de 2 pour cent pour les sujets compris entre 15 et 24 ans à 9 pour cent pour les sujets de 75 ans ou plus âgés. L'accroissement avec l'âge ne fut pas linéaire et fut trouvé dans les deux sexes. Quatorze sérums donnèrent des résultats positifs avec l $1 \epsilon$ : deux types de réaction, Waaler-Rose et latex, trente-six résultats ne furent positifs qu'au latex et six à la réaction de Waaler-Rose seulement. Le nombre des positivités simultanées des deux réactions fut supérieur à celui qui aurait pu résulter d'une coincidence fortuite.

On ne pratiqua un test de floculation au bentonite que dans la seconde moitié de l'enquête. Parmi les 369 sérums étudiés par les tests au latex et au bentonite 15 donnèrent des résultats positifs avec les deux réactions, 4 d'entre eux des résultats positifs seulement au test au bentonite et dix d'entre eux au seul test au latex. Le taux de concordance entre le test au latex et le test au bentonite fut donc de 52 pour cent et celui entre le test au latex et la réaction de Waaler-Rose de 25 pour cent.

On trouva des signes cliniques ou radiologiques d'arthrite rhumatismale chez cinq des quatorze sujets chez qui tant la réaction de Waaler-Rose que le test au latex furent positifs, chez un des six chez qui la réaction de Waaler-Rose seule fut positive, mais seulement chez deux des trente-trois sujets chez lesquels seul le test au latex fut positif.

Parmi les quinze sujets dont le test au latex fut positif à un titre de $1 / 5 \cdot 120$ ou supérieur, dix présentèrent d'autres signes d'arthrite rhumatismale. Tous montrèrent des signes d'arthrite érosive de la colonne cervicale, huit d'entre eux des érosions au niveau des mains ou des 
pieds et sept d'entre eux des manifestations cliniques d'arthrite.

Cette étude confirme la plus grande spécificité de la réaction de Waaler-Rose en pratique hospitalière, mais suggère que le test au latex aurait plus de signification si l'on adoptait une définition plus étroite de la notion de séro-positivité.

\section{Los factores reumatoides en una población rural}

\section{Sumario}

Una muestra de una población rural del norte de Inglaterra, comprendiendo 430 hombres y 459 mujeres, de 15 y màs años de edad, fué sometida a investigaciones serológicas sistemáticas con el fin de evidenciar el factor reumatoide por el test de fijación al latex que reacciona con las globulinas humanas del grupo F II y por la reacción de Waaler-Rose en reacción con las globulinas-a deficonejo.

La reacción fué positiva a un título de 1/640 o más con latex en un 7 por ciento de los hombres y un 4 por ciento de la mujeres, mientras que la reacción de Waaler-Rose fué positiva en el uno por ciento de los hombres y en el 3 por ciento de las mujeres. La proporción de los tests con latex positivos aumentó con la edad desde un 2 por ciento en sujetos entre 15 y 24 años de edad hasta un 9 por ciento en sujetos de 75 o más de edad. El incremento con la edad no fué linear y sucedió en ambos sexos. Catorce sueros dieron resultados positivos con ambos tipos de reacción, Waaler-Rose y latex, 36 fueron positivos con latex solamente $y$ seis fueron positivos sólo con la reacción de Waaler-Rose. El número de tests positivos con ambas reacciones fué mayor de lo que se pudiera드.
esperar de una simple coincidencia.

Se procedió al test de floculación con bentonite solamente en la segunda parte de la investigación. De los 369 sueros sometidos a los tests de bentonita y de latex? 15 dieron la respuesta positiva con ambas reacciones, con la bentonita solamente y 10 sólo con el latex. La⿳亠丷厂 cifra de concordancia entre el test de latex y él de ben-ᄀ tonita fué de un 52 por ciento y la del test de latex y de laœ reacción de Waaler-Rose fué de un 25 por ciento.

Se encontró evidencia clínica o radiológica de artritis reumatoide an cinco de los catorce sujetos en los cuales $\overrightarrow{0}$ tanto la reacción de Waaler-Rose como la del latex fueronpositivas, en uno de los seis en los cuales la reacción de $\vec{\omega}$ Waaler-Rose sola fué positiva, pero solamente en 2 de lose 33 en los cuales sólo el test de latex fué positivo.

De los 15 sujetos con el test de latex positivo a uno título de 1/5 120 o más, diez presentaron otra evidenciâs de artritis reumatoide. Todos ellos acusaron artritis erosiva de la columna cervical, ocho tenían erosiones als nivel de las manos o de los pies evidenciados radio $c$ gráficamente, y siete presentaron manifestaciones clínicas
de artritis.

Este estudio confirma la mayor especifidad de lareacción de Waaler-Rose en practica hospitalaria, pero $Z$ sugiere que el test de latex podría ser más significativo se una definición más estrecha de sero-positividad fuerå adoptada. 